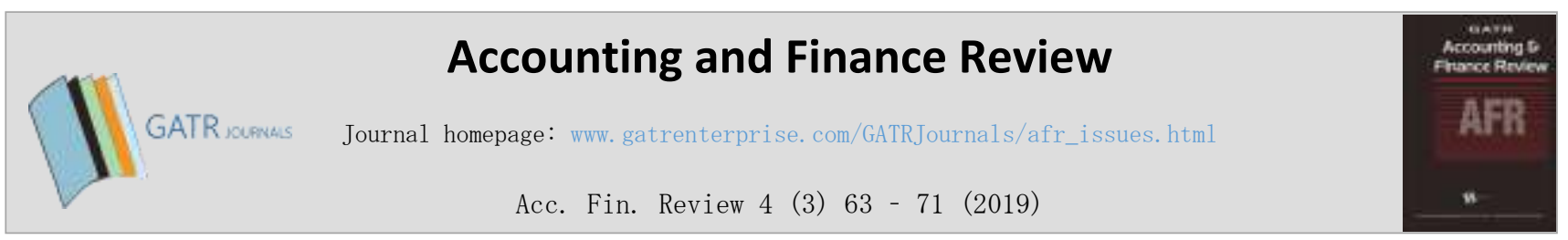

\title{
Implementation of Village Financial System Applications: Empirical Evidence from Indonesia
}

\author{
Sri Rahayu ${ }^{1}$, Kurnia ${ }^{2}$, Djusnimar Dzulistina ${ }^{3}$ \\ ${ }^{1,2,3}$ Department of Accounting, School of Economic and Business, Telkom University, \\ Jl. Telekomunikasi No. 1, 40257, Bandung, Indonesia
}

\begin{abstract}
Objective - The study aims to evaluate the successful implementation of the village financial system.

Methodology/Technique - This research was conducted in the Karangpawitan district of Garut, Indonesia which has 40 villages. Evaluation of the success of the implementation of this system uses the adopts and incorporates the Technology Acceptance Model and the updated DeLone and McLean models referring to information systems implementation research in the public sector.

Findings - The variables used are information quality, management support, perceived ease of use, perceived usefulness, service quality, system quality, training, behavioral intention, user satisfaction, and user involvement. As an analytical tool PLS is used which shows the results of research there are an influence system quality on management support, training, and user involvement. Service quality on management support, user involvement on perceived ease of use, training on perceived usefulness, behavioral intention on user satisfaction. From the results of the opinion of the respondents that the most important is the need for management support so that the implementation of the system can be successful.

Novelty - The model presented is expected to be input in paying attention to variables that can be used for decision making and as a tool to evaluate the implementation of this information system, for the future research can be done with a wider population so that it can reflect comprehensive results.
\end{abstract}

Type of Paper: Empirical

Keywords: Village Financial System, TAM, Implementation, DeLone and McLean, Information System

Reference to this paper should be made as follows: Rahayu, S; Kurnia; Dzulistina, D; (2019). Implementation of Village Financial System Applications: Empirical Evidence from Indonesia, Acc. Fin. Review, 4 (3): 63 - 71 https://doi.org/10.35609/afr.2019.4.3(1)

JEL Classification: G40, G41, G49.

\section{Introduction}

The Village Law has placed villages as the spearhead of development and improvement in community welfare.

\footnotetext{
* Paper info: Revised: October 10, 2019

Accepted: December 10, 2019

* Corresponding author: Sri Rahayu

E-mail: srirahayu@telkomuniversity.ac.id.

Affiliation: Department of Accounting, School of Economic and Business, Telkom University, Indonesia
} 
Villages are given adequate authority and funding resources to be able to manage their own potential to improve both economy and welfare of their communities. Every year the Central Government has budgeted a village fund that is large enough to be given to each village (Indonesia, 2017). At first, when time village funds distributed in 2015, they raised the issue of the many village heads who did not understand the government's financial system (Detikfinance, n.d.). The application of SISKEUDES until December 2018 shows that $93 \%$ of villages have received village funds from the total number of villages in Indonesia as many as 74,957 villages. Before SISKEUDES was launched, most villages made budgets, books and financial reports using MS-Excel or other non-standard applications. This makes it difficult for the district/city government to evaluate the APBDes and village financial reports. Obstacles in implementing SISKEUDES throughout Indonesia include the lack of commitment from the provincial and district/city governments in implementation, unavailable training or technical guidance budgets, zero have human resources in some districts or no technical capacity to assist villages, manual systems with MS-Excel preference, and low capacity of village personnel to meet Central Government standards in managing village finances. Many village heads who do not know about government finances, and the education level conditions of village heads are $40 \%$ poorly educated (elementary and junior high school graduates), so they need assistance in implementing this financial system. The village financial system is expected to help facilitate complicated village fund accounting because the village financial system is far more complicated than the financial systems of multinational companies. Public administrations must carefully determine the skill necessary for the accounting staff to work within an Integrated Financial System (Equey, Bernard, \& Balzli, 2013).

The application of Information Systems/Information Technology has an important role in an organization, namely supporting business process operations, assisting decisions by employees and managers, and aiding strategies for a competitive advantage (O’Brien \& Marakas, 2007). The development of information systems in companies plays a very important role in improving the quality of service to consumers, shortening cycle times, and reducing costs (HassabElnaby, 2012). It has been recognized that Information Systems are not only solutions, but also a competitive advantage for a company. However, because this system is always developing and making its application very expensive, so in order to reduce the costs of its implementation, organizations must know the factors that influence the success of the information system application (Zaied, 2015). After a system is implemented, post-implementation review can be conducted, namely a thorough evaluation of a new, applied system to determine whether the system has been running as expected, and whether it has fulfilled user satisfaction. Evaluation is done after the user has had the opportunity to understand the application, and information system has time to resolve the final implementation errors or problems (Moeller, 2010).

The successful implementation of the system in the village government is expected for villages to be more independent in managing the government and various owned natural resource, including the management of financial and wealth at the village. Indeed, the bigger the role of the village, the greater the responsibility. Therefore, village government must be able to apply the principles of transparency and accountability considering that in village financial management specifically for the village level. Moreover, the village government can conduct village financial management cycle well starting from planning, implementation, administration, reporting, accountability, and supervision. If it is successfully implemented, the village escort will achieve the expected goal, namely Good Village Governance.

To measure the success of an effective information system is very difficult (Furukawa \& Minami, 1995). Necessary tools are needed to measure it. There are many methods having been put forward by experts to help measure the success of a system, and those are from (Biley, J E, Pearson, S.W., Science, S.M., 1983), (Seddon, 1997), (Delone \& Mclean, 2003), (Davis, 1985). TAM is one of the models built to analyze and 
understand the factors that influence the acceptance of the computer technology usage. TAM explains the causal relationship between beliefs (of the benefits in an information system and the ease of use) and the behavior, goals/needs, and users' actual usage of an information system. This model uses users (usage) as the dependent variable, and perceived usefullnes and ease of usage as independent variables. Both of these independent variables are considered to explain user behavior (usage) (Davis, 1985). Furthermore, DeLone and McLean's information success system is a model that can be used to measure the success of the implementation of an information system by using its success reference with information quality, system quality, service quality, use, user satisfaction, and net benefits (Delone \& Mclean, 2003). Referring to the TAM and D\&M updated model, referring to research by (Zaied, 2012) who uses an integrated model in assessing success for the implementation of information systems in the public sector, this study uses an integrated model to assess the success of information systems with ten dimensions in its measurement including behavior intention, information quality, management support, perceived ease of use, perceived usefulness, service quality, system quality, training, user satisfaction, and user involvement.

\section{Literature Review}

\subsection{Village Financial System (SISKEUDES)}

The Village Financial System is an application which is an implementation of the financial control system at village level. SISKEUDES was developed by the Financial and Development Supervisory Agency (BPKP) and the Ministry of Internal Affairs of the Republic of Indonesia which has been implemented since November 2015. Immediate implementation and evaluation are carried out by commission 11 of the Republic of Indonesia People's Representative Council. The Village Financial System is an application for budgeting, bookkeeping, and village financial reporting. District/city governments can also use SISKEUDES to compile village income and expenditure budgets as well as reports on the realization of all village income and expenditure budgets. The governance structure in the village consists of the village head and village officials, namely the village secretary, the head of affairs, and the section head as the user of the village financial system. The hope that the government implementing SISKEUDES can support the implementation of village laws, among others, is that SISKEUDES allows the making and reporting of village budgets to be more timely and accurate, making the disbursement of funds from the central government timely. Implementation of standard software will lead to increased effectiveness and efficiency in public sector organization (Gulledge et al., 2006). This application increases village financial accountability because records and reports in SISKEUDES are controlled and cannot be changed. SISKEUDES makes it easy for district/city governments to compile reports on the realization of village income and expenditure budgets in their area, and these reports will be an attachment to the district/city government financial reports audited by the Supreme Audit Agency (BPK).

\subsection{Integrated Success Model}

The success of an organization is how far organizations can utilize technology, the expertise of human resources and all available resources efficiently to improve services which satisfy members and also customers. Research to evaluate the implementation success of information systems has been conducted numerously, as previously stated this research uses the model proposed in the study (Zaied, 2012) which combines the TAM and D\&M models as updated models to measure the system implementation success. The dimensions used are intention behavior, information quality, management support, perceived ease of use, perceived usefulness, service quality, system quality, training, user satisfaction, and user involvement as illustrated in Figure 1. 


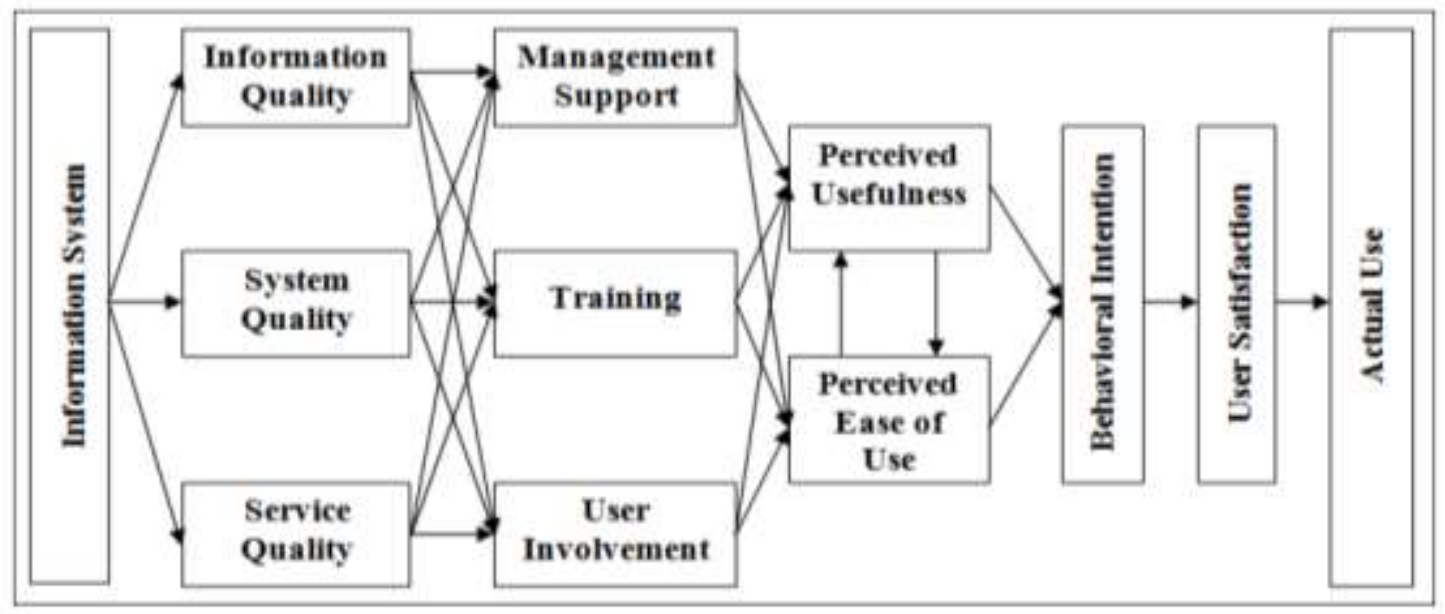

Figure 1. Integrated Success Model (ISM)

The measurements used for each element contained in the Integrated Success Model (ISM) above are, namely (Zaied, 2012):

Table 1. Integrated Success Model Elements

\begin{tabular}{|c|c|c|}
\hline No. & Dimensions & Elements \\
\hline 1. & Information Quality & "Completeness, Understandability, Security, Availability, Accuracy \\
\hline 2. & System Quality & Reliability, Usability, Adaptability, Trust, Maintainability \\
\hline 3. & Service Quality & Availability, Reliability, Integrity, Functionality, Efficiency \\
\hline 4. & Management Support & $\begin{array}{l}\text { Management's encouragement, Providing all necessary resources, } \\
\text { Discussing problems associated with the system, Appreciating the optimal } \\
\text { use of the system, Having sufficient knowledge of the system }\end{array}$ \\
\hline 5. & Training & $\begin{array}{c}\text { Training programs on the application, The clearance of training programs, } \\
\text { Users role, Availability of training material, Support }\end{array}$ \\
\hline 6. & User Involvement & $\begin{array}{l}\text { User's involvement in input design, Perceptions of service evaluations, } \\
\text { Perceived value, Customer attitude }\end{array}$ \\
\hline 7. & Perceived Usefulness & Performance, Effectiveness, Productivity, Risk perception, trust \\
\hline 8. & Perceived Ease of Use & Easy to learn, Easy to manage, Self efficiency, Simplicity, Compability \\
\hline 9. & Behavioral Intention & $\begin{array}{c}\text { Personalization, Interactivity, Response time, Uncertainty avoidance, } \\
\text { Number of transactions executed }\end{array}$ \\
\hline 10. & User Satisfaction & Self efficacy, Repeat visits, Personalization, Perceived risk, Enjoyment \\
\hline
\end{tabular}

This study will examine each relationship of the used ISM model which illustrates that there is an influence of information quality(Jang, 2010) (Y. Wang, 2008), system quality (G. Udo, K. Bagchi., 2010)(C. Liao, J. Chen, 2007)(C. Sohn, 2008), and service quality (A Zaied, 2007) (R. Connolly, 2008), respectively on management support (E. Ngai, T. Cheng, 2004), training (V. Aggelidis, 2009), and user involvement (A. Sorebo, O Sorebo, 2007). These in turn perceived usefulness (C. Yi, P. Liao, C. Huang, 2009) and perceived ease of use (M. Turner, B. Kitchenham, P. Brereton, S. Charters, 2010) which will have an impact on behavioral Intention (Park, 2009) and user satisfaction(C. Flavia'n, M. Guinali'u, 2006)(C. Liao, J. Chen, 2007), so actual use ultimately appears as a result of user satisfaction.

As a support for the results of previous studies, there is a positive effect of system quality on perceived usefulness and ease of use (Cheong, J. H., \& Park, 2005). Information quality produced by information 
systems will affect the perceived usefulness (Seddon, 1997). Perceived information quality positively affects perceived ease of use and perceived usefulness (shih, H., 2004). Service quality has a positive influence on perceived usefulness and perceived ease of use (Ahn, T., Ryu, S., \& Han, 2007). According to (Adam, Nelson, \& Todd, 1992; Igrabia, Guimaraes, \& Davis, 1995, Mao \& Palvia, 2006) in (Tri Cahya, W., G., Wing, W., W \& Adhistya, E., 2014) that perceived usefulness and perceived ease of use have positive relationships and influences. Behavioral intention has a strongger effect on IS success (Zaied, 2012). Based on the description above, the research hypotheses are formulated as follows:
H1 : Information quality influences management support
$\mathrm{H} 2$ : Information quality influences training
H3 : Information quality influences user involvement
H4 : System quality influences management support
H5 : System quality influences training
H6 : System quality influences user involvement
H7 : Service quality influences management support
H8 : Service quality influences training
H9 : Service quality influences user involvement
H10 : Management support influences perceived usefulness
H11 : Management support influences perceived ease of use
H12 : Training influences perceived usefulness
H13 : Training influences perceived ease of use
H14 : User involvement influences perceived usefulness
H15 : User involvement influences perceived ease of use
H16 : Perceived usefulness influences behavioral intention
H17 : Perceived ease of use influences behavioral intention
H18 : Behavioral intention influences user satisfaction

\section{Research Methodology}

The research method used in this study is quantitative by using a closed questionnaire referring to the questionnaire (Zaied, 2012) which is presented with questions and choices of answers and respondents are asked to choose one of the answers according to the conditions of the respondents. The questionnaire uses a Likert scale with a score of 1 to 5. Data from the questionnaire were analyzed using Partial Least Square (PLS). The sample of this study is village apparatuses in the Karangpawitan sub-district, Garut Regency, Indonesia, which has 20 villages. Each village consists of four representative vilage apparatuses, which had to fill out questionnaires related to SISKEUDES, namely the village head, village secretary, head of financial affairs, and village technical implementers. The questionnaire was distributed using google form, and the distribution of samples collected based on education level, namely $78.57 \%$ high school, $14.28 \%$ professional diploma, and $7.14 \%$ university degree.

\section{Results and Discussion}

The results of processing using smartPLS are shown in table 2 which shows that not all hypotheses are accepted. The hypotheses accepted from the results of table 2 above are:

System quality has an effect on management support (H4) which means that the increasing system quality that is felt to meet reliability, usability adaptability, trust, privacy, and maintability. This cause management to be satisfied so that support from management support continues to increase in terms of continuously using the system and being responsive against all problems that occur. 
System quality has an effect on training (H5). This influence shows that system quality is increasing, so it will improve the training program which is felt to provide benefits and completeness of materials supporting the success of the program.

System quality has an effect on user involvement (H6). This increasing system quality will create the desire of users to always be involved in providing inputs or in design activities conducted for the success of the program in both input and output designs.

Service quality has an effect on management support (H7) by the increasing service quality with the ease of information accessed, integrity, efficiency and funtionality so management will always improve its support.

Training has an effect on perceived usefulness (H12). This means that the increase in the activities of the training program related to the implementation of the system, and the availability of complete materials will increase the perceived usefulness of continuously increasing performance, effectiveness and productivity.

Training has an effect on perceived ease of use (H13), the higher the intensity of training, the easier the users in in operating the system. Therefore, they become more skillful.

User involvement has an effect on perceived ease of use (H15), which means that the increasing involvement of users in the design stages will increase the ease of operating the system during its implementation.

Behavioral intention affects user satisfaction (H19) to increase behavioral intention which includes personalization, interactivity, response time, uncertainty, number of transactions, and number of system visits. This, in turn, will increase user satisfaction so that the success of implementing a system can be easily achieved.

Table 2. Path Coefficients (Mean, STDEV, T-Values)

\begin{tabular}{|c|c|c|c|c|c|}
\hline & $\begin{array}{c}\text { Original } \\
\text { Sample (O) }\end{array}$ & $\begin{array}{c}\text { Sample } \\
\text { Mean (M) }\end{array}$ & $\begin{array}{c}\text { Standard } \\
\text { Deviation } \\
(\text { STDEV })\end{array}$ & $\begin{array}{c}\text { Standard Error } \\
(\text { STERR })\end{array}$ & $\begin{array}{c}\text { T Statistics } \\
(\mid \mathrm{O} / \text { STERR } \mid)\end{array}$ \\
\hline Behavioral Intention -> User Satisfaction & 0.691507 & 0.719977 & 0.043660 & 0.043660 & 15.838622 \\
\hline $\begin{array}{c}\text { Information Quality -> Management } \\
\text { Support }\end{array}$ & -0.358759 & -0.277733 & 0.251843 & 0.251843 & 1.424536 \\
\hline $\begin{array}{c}\text { Information Quality -> Training } \\
\text { Information Quality -> User Involvement }\end{array}$ & -0.104858 & -0.009581 & 0.160462 & 0.160462 & 0.653476 \\
\hline $\begin{array}{c}\text { Management Support -> Perceived Ease of } \\
\text { Use }\end{array}$ & -0.030087 & -0.023781 & 0.073738 & 0.073738 & 0.408023 \\
\hline $\begin{array}{c}\text { Management Support -> Perceived } \\
\text { Usefulness }\end{array}$ & -0.082012 & -0.069239 & 0.052872 & 0.052872 & 1.551120 \\
\hline Training -> Perceived Ease of Use & -0.084190 & -0.101594 & 0.210945 & 0.210945 & 0.399110 \\
\hline Training >> Perceived Usefulness & 0.860476 & 0.779352 & 0.232655 & 0.232655 & 3.698502 \\
\hline $\begin{array}{c}\text { Perceived Ease of Use -> Behavioral } \\
\text { Intention }\end{array}$ & -0.175433 & 0.299139 & 0.564508 & 0.564508 & 0.310772 \\
\hline $\begin{array}{c}\text { Perceived Usefulness -> Behavioral } \\
\text { Intention }\end{array}$ & 1.030201 & 0.325432 & 0.770510 & 0.770510 & 1.337038 \\
\hline Service Quality -> Management Support & 0.017761 & 0.002250 & 0.098866 & 0.098866 & 0.179649 \\
\hline Service Quality -> Training & 0.539679 & 0.495113 & 0.270962 & 0.270962 & 1.991714 \\
\hline Service Quality -> User Involvement & 0.203639 & 0.235863 & 0.217567 & 0.217567 & 0.935983 \\
\hline
\end{tabular}




\begin{tabular}{|c|c|c|c|c|c|}
\hline System Quality -> Management Support & 0.282894 & 0.263586 & 0.091802 & 0.091802 & 3.081588 \\
\hline System Quality -> Training & 0.340878 & 0.327725 & 0.081966 & 0.081966 & 4.158786 \\
\hline System Quality -> User Involvement & 0.398609 & 0.370209 & 0.081372 & 0.081372 & 4.898609 \\
\hline $\begin{array}{c}\text { User Involvement -> Perceived Ease of } \\
\text { Use }\end{array}$ & 0.881909 & 0.783846 & 0.276665 & 0.276665 & 3.187641 \\
\hline \begin{tabular}{c} 
User Involvement -> Perceived Usefulness \\
\hline
\end{tabular} & -0.028450 & 0.068354 & 0.235069 & 0.235069 & 0.121027 \\
\hline
\end{tabular}

From the results of the answers given by respondents to the most important thing felt in the successful implementation of this system is management support, but this does not mean that other things are not important. the following is the rank of participants' agreements, namely:

Table 3. Participants Agreements

\begin{tabular}{|c|c|c|c|c|c|c|c|}
\hline & $\begin{array}{c}\text { Strongly } \\
\text { agree }\end{array}$ & agree & average & disagree & $\begin{array}{c}\text { Strongly } \\
\text { disagree }\end{array}$ & $\begin{array}{c}\text { Strongly agree } \\
+ \text { agree }\end{array}$ & Rank \\
\hline Management Support & $25,00 \%$ & $75,00 \%$ & $0,00 \%$ & $0,00 \%$ & $0,00 \%$ & $100,00 \%$ & 1 \\
\hline User Satisfaction & $9,18 \%$ & $84,69 \%$ & $4,08 \%$ & $2,04 \%$ & $0,00 \%$ & $93,88 \%$ & 2 \\
\hline Perceived Usefulnes & $15,48 \%$ & $73,81 \%$ & $5,95 \%$ & $4,76 \%$ & $0,00 \%$ & $89,29 \%$ & 3 \\
\hline Service Quality & $10,53 \%$ & $77,89 \%$ & $9,47 \%$ & $2,11 \%$ & $0,00 \%$ & $88,42 \%$ & 4 \\
\hline Information Quality & $12,70 \%$ & $71,43 \%$ & $7,94 \%$ & $7,94 \%$ & $0,00 \%$ & $84,13 \%$ & 5 \\
\hline Behavioral Intention & $11,11 \%$ & $73,02 \%$ & $11,90 \%$ & $3,97 \%$ & $0,00 \%$ & $84,13 \%$ & 6 \\
\hline System Quality & $9,74 \%$ & $72,73 \%$ & $12,34 \%$ & $3,90 \%$ & $1,30 \%$ & $82,47 \%$ & 7 \\
\hline Measuring Training & $14,29 \%$ & $67,86 \%$ & $10,71 \%$ & $0,00 \%$ & $7,14 \%$ & $82,14 \%$ & 8 \\
\hline $\begin{array}{c}\text { Perceived Easy of } \\
\text { Use }\end{array}$ & $7,94 \%$ & $70,63 \%$ & $14,29 \%$ & $7,14 \%$ & $0,00 \%$ & $78,57 \%$ & 9 \\
\hline User Involement & $14,29 \%$ & $46,43 \%$ & $35,71 \%$ & $3,57 \%$ & $0,00 \%$ & $60,71 \%$ & 10 \\
\hline
\end{tabular}

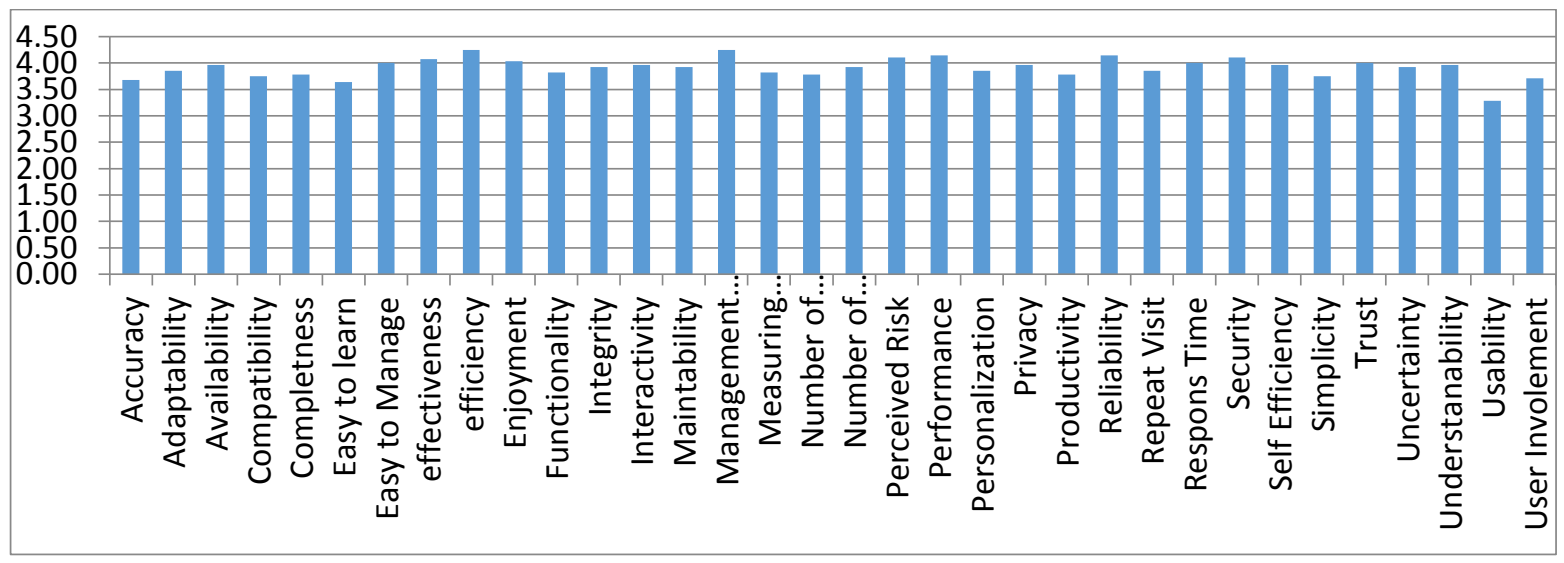

Figure 2. Elements Importance

Judging from the elements used to measure the variables in ISM, the most important points are management support and efficiency. These are mostly felt by the users of the village financial system which has been implemented. The system that has been used is proven to be able to improve work efficiency and very helpful in completing tasks. Users feel the importance of continuous support from management. This is in line with the idea that ERP implementation can change organizations, standardized performance measurement, and more efficient and effective management accounting techniques (Spraakman, 2014), and 
ERP implementation in the public sector will have an impact on increasing organizational effectiveness and efficiency (Gulledge et al., 2006).

\section{Conclusion}

Based on empirical findings, this study reached several conclusions. Result of the empirical analysis indicated that system quality has a strong influence on management support, training, and user involvement. Service quality has a strong influence on management support. Training has a strong influence on perceived usefulness and perceived ease of use. User involvement has a strong influence on perceived ease of use. Behavioral intention has a strong influence on user satisfaction. Finally, important elements that must be considered in the successful implementation of the village financial system are both efficiency and management support as a concern for evaluation and implementation of SISKEUDES, which is also inseparable from the support of other elements. Subsequent research can examine regional coverage in Indonesia as a whole, so the results obtained can illustrate the implementation results of the village financial system nationally.

\section{References}

Aggelidis, V. P., \& Chatzoglou, P. D. (2009). Using a modified technology acceptance model in hospitals. International journal of medical informatics, 78(2), 115-126. https://doi.org/10.1016/j.ijmedinf.2008.06.006

Ahn, T., Ryu, S., \& Han, I. (2007). The impact of Web quality and playfulness on user acceptance of online retailing. Information \& management, 44(3), 263-275. https://doi.org/10.1016/j.im.2006.12.008

Bailey, J. E., \& Pearson, S. W. (1983). Development of a tool for measuring and analyzing computer user satisfaction. Management science, 29(5), 530-545. https://doi.org/10.1287/mnsc.29.5.530

Chin-ChehYi, P. W. L., Huang, C. F., \& Hwang, I. H. (2010). Acceptance of mobile learning: A respecification and validation of information system success. International Journal of Human and Social Sciences, 5(7). https://s3.amazonaws.com/academia.edu.documents/41008424/v5-7-70.pdf?response-content-

disposition=inline\%3B\%20filename\%3DAcceptance_of_Mobile_Learning_a_Respecif.pdf\&X-Amz-

Algorithm=AWS4-HMAC-SHA256\&X-Amz-Credential=AKIAIWOWYYGZ2Y53UL3A\%2F20191225\%2Fus-east-

1\%2Fs3\%2Faws4_request\&X-Amz-Date $=20191225 T 075729 Z \& X-A m z-E x p i r e s=3600 \& X-A m z-$

SignedHeaders $=$ host $\& X-A m z-S i g n a t u r e=57704 d 8 d 2628 f 843 \mathrm{bac} 73 \mathrm{cca} 2 \mathrm{caec} 1739 \mathrm{~b} 51 \mathrm{a} 0 \mathrm{a} 31 \mathrm{c} 33 \mathrm{e} 46 \mathrm{adaa} 1 \mathrm{aebd} 5 \mathrm{a} 9 \mathrm{c} 3 \mathrm{fcc}$

Ho Cheong, J., \& Park, M. C. (2005). Mobile internet acceptance in Korea. Internet research, 15(2), 125-140.

https://doi.org/10.1108/10662240510590324

Davis, F. D. (1985). A technology acceptance model for empirically testing new end-user information systems: Theory and results (Doctoral dissertation, Massachusetts Institute of Technology).

Delone, W. H., \& McLean, E. R. (2003). The DeLone and McLean model of information systems success: a ten-year update. Journal of management information systems, 19(4), 9-30. https://doi.org/10.1080/07421222.2003.11045748

Detikfinance. (n.d.). No Title. 2018. Retrieved from https://m.detik.com/finance/berita-ekonomi-bisnis/d-4474096/adasiskeudes-pengelolaan-dana-desa-jadi-lebih-mudah

Ngai, E. W. T., Cheng, T. C. E., \& Ho, S. S. M. (2004). Critical success factors of web-based supply-chain management systems: an exploratory study. Production Planning \& Control, 15(6), 622-630. https://doi.org/10.1080/09537280412331283928

Equey, C., Bernard, B., \& Balzli, C. E. (2013). The impact of an Integrated Financial System implementation on accounting profiles in a public administration an ethnographic approach. https://doi.org/10.1108/18325911211258344

Furukawa, M., \& Minami, A. (1995). A Study on the 'Flexibility' of Information Systems (Part 1): Why do they need to be flexible?, (Part 1), 1-13. https://doi.org/10.5539/ijbm.which

Flavián, C., Guinalíu, M., \& Gurrea, R. (2006). The role played by perceived usability, satisfaction and consumer trust on website loyalty. Information \& management, 43(1), 1-14. https://doi.org/10.1016/j.im.2005.01.002

Udo, G. J., Bagchi, K. K., \& Kirs, P. J. (2010). An assessment of customers'-service quality perception, satisfaction and intention. International Journal of Information Management, 30(6), 481-492. https://doi.org/10.1016/j.ijinfomgt.2010.03.005 
Gulledge, T. R., Sommer, R. A., Gulledge, T. R., Policy, P., Sommer, R. A., \& Policy, P. (2006). Public sector enterprise resource planning Public sector enterprise resource planning. https://doi.org/10.1108/02635570310489179 HassabElnaby, H. R., Hwang, W., \& Vonderembse, M. A. (2012). The impact of ERP implementation on organizational capabilities and firm performance. Benchmarking: An International Journal, 19(4/5), 618633.https://doi.org/10.1108/14635771211258043

Indonesia, K. K. R. (2017). Buku saku Dana Desa.

Indonesia, K. K. R. (2017). Village Fund pocket book Retrieved from https://www.kemenkeu.go.id/media/6750/bukusaku-dana-desa.pdf

Jang, C. (2010). Measuring Electronic Government Procurement Success and Testing for the Moderating Effect of Computer Selft-efficacy. International Journal of Digital Content Technology and Its Applications, 4(3), $224-232$.

Liao, C., Chen, J. L., \& Yen, D. C. (2007). Theory of planning behavior (TPB) and customer satisfaction in the continued use of e-service: An integrated model. Computers in human behavior, 23(6), 2804-2822. https://doi.org/10.1016/j.chb.2006.05.006

O’Brien, J., \& Marakas, G. (2007). Management Information System (8th ed.). Boston: Mc Graw Hill, Inc.

Park, S. Y. (2009). An analysis of the technology acceptance model in understanding university students' behavioral intention to use e-learning. Educational technology \& $\quad$ society, 12(3), 150-162. https://www.jstor.org/stable/jeductechsoci.12.3.150

R. Connolly, F. B. (2008). eTax Filing \& Service Quality: The case of the revenue online service. In World Academy of Science, Engineering and Technology (pp. 313-317).

Seddon, P. B. (1997). A respecification and extension of the DeLone and McLean model of IS success. Information systems research, 8(3), 240-253. https://doi.org/10.1287/isre.8.3.240

Shih, H. P. (2004). An empirical study on predicting user acceptance of e-shopping on the Web. Information \& management, 41(3), 351-368. https://doi.org/10.1016/S0378-7206(03)00079-X

Spraakman, C. S. G. (2014). ERP systems and management accounting: a multiple case study. https://doi.org/10.1108/11766091211282689

Sohn, C., \& Tadisina, S. K. (2008). Development of e-service quality measure for internet-based financial institutions. Total Quality Management, 19(9), 903-918. https://doi.org/10.1080/14783360802224412

Sørebø, A. M., Sørebø, Ø., \& Sein, M. K. (2008). The influence of user involvement and personal innovativeness on user behavior. International Journal of Human and Social Sciences, 3(5), 326-331. https://www.researchgate.net/profile/Anne_Sorebo/publication/239540912_The_Influence_of_User_Involvement_and_ Personal_Innovativeness_on_User_Behavior/links/0046352a1b26a94ac4000000/The-Influence-of-User-Involvementand-Personal-Innovativeness-on-User-Behavior.pdf

Tri Cahya, W., G., Wing, W., W \& Adhistya, E., P. (2014). Evaluation of the Success of the Implementation of the Learning Task Management Application at BPK. In 2014 National Seminar (pp. 10-17 ISSN 1979-2328). Yogyakarta.

Turner, M., Kitchenham, B., Brereton, P., Charters, S., \& Budgen, D. (2010). Does the technology acceptance model predict actual use? A systematic literature reviews. Information and software technology, 52(5), 463-479. https://doi.org/10.1016/j.infsof.2009.11.005

Y. Wang, Y. L. (2008). Assessing eGovernment Systems Success: A validation of the DeLone and McLean model of information system success. Government Information Quarterly, 25, 717-733.

Zaied, A. N. H. (2012). An integrated success model for evaluating information system in public sectors. Journal of Emerging Trends in Computing and Information Sciences, 3(6), 814-825. https://pdfs.semanticscholar.org/995f/3e281fd842df1f1c7588d3ffd9bd2d6c0578.pdf

Zaied, A. N. H., \& Al-Khairalla, F. (2007). Risk assessment for implementing e-services in some ministries in the State of Kuwait. Arab Gulf Journal of Scientific Research, 25(3), 138. https://www.researchgate.net/profile/Abdel_Nasser_Zaied/publication/283772684_Risk_Assessment_for_Implementin g_E-Services_in_Some_Ministries_in_the_State_of_Kuwait/links/5646cd2d08aef646e6cde1bd/Risk-Assessment-forImplementing-E-Services-in-Some-Ministries-in-the-State-of-Kuwait.pdf

Zaied, A. N. H. (2015). An Integrated Success Model for Evaluating Information System in Public An Integrated Success Model for Evaluating Information System in Public Sectors, (November). 